\title{
Poultry Litter Ash Reduces Phosphorus Losses during Greenhouse Production of Lantana camara L. 'New Gold'
}

\author{
Daniel E. Wells ${ }^{1,2}$, Jeffrey S. Beasley, Lewis A. Gaston, Edward W. Bush, \\ and Maureen E. Thiessen \\ Louisiana State University Agricultural Center, 101 Efferson Hall, Baton \\ Rouge, LA 70803 \\ Additional index words. Lantana camara 'New Gold', dissolved reactive phosphorus, total \\ phosphorus, leachate, effluent
}

\begin{abstract}
Phosphorus (P) fertilizers with high water-solubility are often applied in excessive amounts to porous horticultural substrates to produce high-quality plants. As a result, high $P$ losses during containerized plant production have presented an environmental challenge to responsible growers. Poultry litter ash (PLA), a byproduct of bioenergy production, contains $P$ concentrations comparable to conventional $P$ fertilizers but is characterized as having lower water-solubility. Therefore, a series of experiments were conducted to characterize effects of PLA on container-plant growth and $P$ leaching. PLA was compared with superphosphate (SP), a highly water-soluble $P$ source, in ratios of 0:100, 25:75, 50:50, 75:25, and 100:0 (SP:PLA) in the production of Lantana camara L. 'New Gold'. In 2011, lantana fertilized with higher ratios of PLA exhibited slower growth with lower shoot and root biomasses compared with $100 \%$ SP-fertilized lantana. However, in 2012, differences in fertilizer treatments lessened, with $100 \%$ PLA-fertilized lantana exhibiting $14 \%$ less shoot biomass and no differences in root biomass compared with $100 \%$ SP-fertilized lantana. Measurement of shoot: root biomass, a common indicator of $P$ deficiency, was not different between any $P$ treatments in 2011 or 2012. This indicates root growth was most likely the driving factor in P-treatment effects on shoot biomass in each year of the experiment. During a postproduction field trial, no differences in growth or biomass were observed between lantana previously fertilized with $P$, regardless of source. However, application of PLA as the single $P$ source reduced dissolved reactive $P$ (DRP) concentrations in leachate $>90 \%$ and total $P$ (TP) mass losses $69 \%$ compared with $100 \%$ SP-fertilized lantana during container production, with $P$ treatments reducing DRP and TP losses as PLA ratios increased. Therefore, the benefit of $P$-loss reduction during container production achieved through PLA application may warrant the acceptance of slightly smaller plants or extending production cycles.
\end{abstract}

Soilless substrates common to nursery and greenhouse production are often characterized as having high percolation rates ( $\mathrm{Zhu}$ et al., 2007) and low P-sorption capacities (Bilderback, 2001; Yeager and Barrett, 1984). Many growers compensate for low $\mathrm{P}$ retention of soilless substrates by applying higher fertilizer rates more frequently (Silber et al., 2005). However, fertility practices that rely on high, frequent fertility rates have been correlated to increased nutrient leaching (Zhu et al., 2007). As a result, nursery and greenhouse operations have been identified as potential contributors to nonpoint-source nutrient pollution (Mangiafico et al., 2008), especially

Received for publication 12 June 2014. Accepted for publication 24 Feb. 2017.

We wish to thank North American Fertilizers, LLC (Benson, MN) for supplying poultry litter ash used in these experiments.

${ }^{1}$ Current address: Department of Horticulture, Auburn University, 101 Funchess Hall, Auburn, AL 36849

${ }^{2}$ Corresponding author. E-mail: wellsda@auburn. edu.

592
2010; Dawson and Hilton, 2011). One recycled $\mathrm{P}$ source in great abundance in the southeastern United States is poultry litter. Poultry litter contains comparable amounts of nitrogen to ruminant wastes, but higher concentrations of $\mathrm{P}$ because fowl are unable to extract organically-bound $\mathrm{P}$ from feeds without the addition of phytase (Woyengo and Nyachoti, 2011). Poultry litter has been primarily used as a fertilizer on pastures and other agricultural commodities. However, continuous application of poultry litter has led to increased incidence of surface-water impairment because of concentrated land applications (Sharpley et al., 1994). Processes to concentrate poultry litter $P$ to reduce associated transportation costs to expand the area of application have included compaction (Bernhart et al., 2010), pelletization (McMullen et al., 2005), composting (Brodie et al., 2000), P extraction (Szogi et al., 2008), gasification (Priyadarsan et al., 2004), or combustion (Codling et al., 2002; Schiemenz and Eicler-Lobermann, 2010). However, many of the concentration processes listed have not been widely adopted to date.

Unlike many processes used to concentrate $\mathrm{P}$, combustion of poultry litter has been reported to reduce manure biomass by $>80 \%$, decrease $\mathrm{P}$ water-solubility, and produce energy (Habetz and Echols, 2006). For example, Fibrominn, a power plant in Benson, $\mathrm{MN}$, is an alternative energy plant that cocombusts poultry litter and wood to provide $\approx 55 \mathrm{MW}$ of energy for 40,000 homes. Combustion of poultry litter converts $\mathrm{P}$ from $50 \%$ to $60 \%$ water-soluble forms in raw poultry litter to $1.5 \%$ water-soluble $\mathrm{P}$ in PLA. More than $80 \%$ of PLA-P is soluble only in hydrochloric acid (Codling, 2006), suggesting that $\mathrm{P}$ will be less prone to offsite movement than from more water-soluble sources. Although PLA-P is present as lowsoluble compounds, PLA has been reported to be a suitable $P$ source for wheat $[($ Triticum aestivum L.) (Codling et al., 2002)], Japanese mustard spinach [(Brassica rapa L.) (Faridullah et al., 2009)], buckwheat (Fagopyrum escultentum Lifago), oil radish (Raphnus sativus oleiformis Adagio), phacelia (Phacelia tanacetifolia Lisette), ryegrass [(Lolium multiflorum westerwoldicum Gordo) (Bachmann and Eichler-Lobermann, 2010)], and ornamental crops (Wells et al., 2013). To date, no published research on the effect of PLA to reduce P leaching from soilless substrates is available. Therefore, experiments were conducted to determine if PLA application is suitable for plant growth and reduces $\mathrm{P}$ leaching within a soilless substrate in container-grown plant production.

\section{Materials and Methods} 2001: Ristvey et al. 2007: Shaviv, 2001; Tyle et al., 1996).

Given the high costs associated with CRFs and increasing concern for P leaching, recycling nutrients, mainly in the form of manures, have been researched as a means to mitigate $\mathrm{P}$ losses during crop production cycles (Bachmann and Eichler-Lobermann,
Plant response and leachate-DRP in a greenhouse experiment. On 6 Sept. 2011 and 2 Mar. 2012, 60 lantana plants (Lantana camara L. 'New Gold') were transplanted from 105-cell trays to $301.6-\mathrm{L}$ containers, with two plants per container. The substrate was composed of pine bark (particle size 
$<0.38 \mathrm{~cm}$ ) and peatmoss at a $4: 1$ ratio (by volume), and amended with $0.89 \mathrm{~kg} \cdot \mathrm{m}^{-3}$ micronutrient package (Micromax; Scotts Company, Marysville, $\mathrm{OH}$ ), potassium (K) (Meister 0-0-43; Graco Fertilizer Company, Cairo, GA) at $0.25 \mathrm{~kg} \cdot \mathrm{m}^{-3} \mathrm{~K}(0 \mathrm{~N}-0 \mathrm{P}-35.7 \mathrm{~K})$, and $2.97 \mathrm{~kg} \cdot \mathrm{m}^{-3}$ pulverized dolomitic limestone. Preplant-incorporated $\mathrm{P}$ treatment sources were either SP or PLA $\left(260 \mathrm{~g} \cdot \mathrm{m}^{-3} \mathrm{P}\right)$, with the latter being a product of commercial energy production via combustion of poultry litter and obtained courtesy of North American Fertilizer, LLC (Benson, MN). Total P, available $\mathrm{P}$, and water-soluble $\mathrm{P}$ of $\mathrm{SP}$ and PLA were determined using the spectrophotometric molybdovanadophosphate method for determining TP in fertilizers (AOAC INTERNATIONAL, 2005b), direct extraction method for determining available $\mathrm{P}$ in fertilizers (AOAC INTERNATIONAL, 2005c), and the spectrophotometric molybdovanadophosphate method for determining water-soluble $\mathrm{P}$ in fertilizers (AOAC INTERNATIONAL, 2005a), respectively. Total $\mathrm{P}$ and water-soluble $\mathrm{P}$ were determined at Louisiana State University's Agricultural Chemistry Department (Baton Rouge, LA), and available $\mathrm{P}$ was determined at Brookside Laboratories, Inc. (New Bremen, OH). PLA was $10 \%$ TP and $6.7 \%$ available $\mathrm{P}, 1 \%$ of which was water-soluble for a total analysis of $0 \mathrm{~N}-3.1 \mathrm{P}-4.2 \mathrm{~K}$. Superphosphate was $20 \% \mathrm{TP}$ and $18 \%$ available $\mathrm{P}, 85 \%$ of which was watersoluble for a total analysis of $0 \mathrm{~N}-8.7 \mathrm{P}-0 \mathrm{~K}$. Superphosphate and PLA were incorporated as single $\mathrm{P}$ sources or in ratios (by \% available $\mathrm{P}$ ) of $25: 75,50: 50$ or $75: 25$ SP:PLA at $260 \mathrm{~g} \cdot \mathrm{m}^{-3}$ $\mathrm{P}$ (Yeager and Barrett, 1985) with controls receiving no $\mathrm{P}$ fertilizer.

Plants were maintained in a greenhouse under natural light for $84 \mathrm{~d}$ at temperatures between 23 and $29{ }^{\circ} \mathrm{C}$. Temperature was recorded using a datalogger (HOBO H08004-02; Onset Computer Corporation, Bourne, MA) and averaged 23.7 and $28.4{ }^{\circ} \mathrm{C}$ in 2011 and 2012, respectively. During the experiment, plants were supplied with $350 \mathrm{~mL}$ water including $120 \mathrm{~mL}$ aliquots of $\mathrm{NH}_{4}$ $\mathrm{NO}_{3}$ (aq.) at a rate of $250 \mathrm{mg} \cdot \mathrm{L}^{-1} \mathrm{~N}$ per container per day.

Lantana growth was measured biweekly using a growth index [(height + widest width + perpendicular width)/3]. Flowers showing color were quantified biweekly. At $84 \mathrm{~d}$ after planting (DAP), lantana shoots and roots were harvested and separated. Roots were washed with a gentle stream of water to remove adhering substrate. Lantana leaf and root tissue samples were collected and rinsed with deionized water to remove exterior salts or contaminants. Shoots and roots, including tissue samples, were dried at $60{ }^{\circ} \mathrm{C}$ for $72 \mathrm{~h}$ before determining biomass gravimetrically. Leaf-tissue samples, in amounts of $0.5 \mathrm{~g}$, were ground in a stainless-steel mill (Thomas Wiley ${ }^{\circledR}$ Mini-Mill; Thomas Scientific, Swedesboro, NJ) to a particle size of $<0.5 \mathrm{~mm}$ and digested according to procedures for wet acid digestion using nitric and perchloric acids described by Mills and Jones (1996). Concentrated samples were diluted with $20 \mathrm{~mL}$ deionized water and analyzed for elemental concentrations using inductively coupled plasma optical emission spectroscopy (ICP-OES; SPECTRO Analytical Instruments, Kleve, Germany).

Leachate from three containers per treatment was collected weekly after the Virginia Tech Pour Through method (Wright, 1986). In the laboratory, $15-\mathrm{mL}$ aliquots of leachate were filtered through $0.45 \mu \mathrm{m}$ disposable nylon filters $\left(22 \mathrm{~mm}\right.$ diameter, Whatman ${ }^{\mathrm{TM}}$; GE Healthcare UK Limited, Buckinghamshire, UK) in preparation for DRP analysis using the molybdate colorimetric method developed by Murphy and Riley (1962) and modified by Pote and Daniel (2000a).

Quantification of TP losses. In 2012, lantana were grown following the same previously outlined procedures. However, these plants were used to quantify effluent-total $\mathrm{P}$ (effluent-TP) by continuously collecting effluent from containers using 18.9-L polypropylene buckets during the 84-d experimental period. To capture total container effluent and minimize evaporative losses, a $15-\mathrm{cm}$ diameter opening was fashioned in each bucket's lid to allow leachate to drain directly from the growing container into the collection bucket. A silicone caulk sealant was applied to seal the container-bucket junction. Bucket lids were placed on top of buckets, but were not fastened to avoid creation of a vacuum and to allow water to move through substrates and into collection buckets.

Total leachate volume was quantified biweekly, and $120-\mathrm{mL}$ aliquots were collected for TP analysis. Total $\mathrm{P}$ was analyzed using the sulfuric acid-nitric acid digestion method for determining TP in water samples (Pote and Daniel, 2000b). Samples (25 mL) were digested in concentrated sulfuric and nitric acids ( $1 \mathrm{~mL}+5 \mathrm{~mL}$, respectively), at $200{ }^{\circ} \mathrm{C}$ for $6 \mathrm{~h}$ on a digestion block (Bran + Luebbe BD-40) controlled with a BD-20/40 controller (Bran + Luebbe, Vallejo, CA) to hydrolyze polyphosphates, organically bound phosphates, and particulate P to orthophosphate. After digestion, samples were neutralized using $\mathrm{NaOH}$ and diluted with distilled water before determination of orthophosphate concentrations using the molybdate colorimetric method for determining orthophosphate concentrations in water samples developed by Murphy and Riley (1962) and modified by Pote and Daniel (2008a). At 84 DAP, lantana shoots and roots were harvested and processed for biomass and leaf/ root tissue elemental concentrations were determined as previously described.

Postproduction field evaluation. In 2012 30 lantana plants were grown concurrently with and under the same treatments and conditions as previously described plants. After an 84-d period in the greenhouse, plants were transplanted into a raised bed to simulate posttransplant field conditions. A linear bed measuring $120 \mathrm{~m}$ long and $1 \mathrm{~m}$ wide composed of native soil (Oliver silt loam; fine-silty, mixed, thermic, typic fragiudalf) and amended via rototillage with a $7.5 \mathrm{~cm}$ layer of pine bark, milled to $<0.95 \mathrm{~cm}$ (Phillips Bark Processing Co., Brookhaven, MS), was established at the Burden Research Center located in Baton Rouge, LA. Granular fertilizer (Sta-Green, $12 \mathrm{~N}-2.6 \mathrm{P}-4.9 \mathrm{~K}$; Spectrum Brands Holdings, Atlanta, GA) was applied to the surface of the bed at 0.97 $\mathrm{kg} \cdot 100 \mathrm{~m}^{-2} \mathrm{~N}$ before transplanting. Plants were transplanted into the bed $1.2 \mathrm{~m}$ apart in a linear row, watered in thoroughly, and were irrigated daily for the duration of the experiment.

Lantana plants were measured weekly to calculate growth index [(height + widest width + perpendicular width)/3] and quantify flowers showing color for the first 4 weeks after transplanting. At 49 DAP, shoots were harvested, dried at $60{ }^{\circ} \mathrm{C}$ for $96 \mathrm{~h}$, and biomass was recorded.

Experimental designs and statistical analyses. An experimental unit was defined as an individual container in greenhouse experiments and as plants removed from individual containers and planted into the landscape in the field experiment. Experimental units were arranged in completely randomized designs with five replications in greenhouse experiments and as a randomized complete block design with five blocks in the field experiment. Growth index, flower count, plant dry weight, tissue nutrient concentration, leachate-DRP and effluent-TP data were analyzed using PROC MIXED (SAS version 9.3; SAS Institute, Cary, NC) and the block was treated as a RANDOM effect in the field experiment. Where appropriate, means for each measurement at each sample date were separated using Tukey's Honest Significant Difference test at a significance level of 0.05 .

\section{Results}

Plant response in greenhouse experiments. Application of $\mathrm{P}$, regardless of P-treatment combination, increased growth index of lantana compared with control at 42,56 , and $70 \mathrm{~d}$ after potting (DAP) in 2011, and at all measurement dates in 2012 (Table 1). When applied as a singular P source, PLA increased growth compared with the control by $75 \%$, $157 \%$, and $178 \%$ at 42,56 , and 70 DAP in 2011 and $72 \%$ at 84 DAP in 2012. As PLA composition of the fertilizer treatment increased, lantana exhibited a pattern of slower growth in 2011 between 28 and 70 DAP. However, less treatment effect was observed in 2012.

Similar to growth indices, shoot dry weight slightly decreased to $17.4,14.6$, 12.0 , and $10.8 \mathrm{~g}$ as the percentage of PLA increased in 2011 compared with $18.2 \mathrm{~g}$ for $100 \%$ SP-fertilized lantana (Table 2). Fertilization with $100 \%$ PLA decreased shoot dry weight by $41 \%$ compared with lantana fertilized with $100 \%$ SP. However, a similar trend was not observed in 2012 as shoot dry weight was reduced only $14 \%$ through fertilization with $100 \%$ PLA, compared with $100 \%$ SP.

In 2011 , root dry weight decreased $28 \%$, from 5.55 to $4.00 \mathrm{~g}$, when plants were fertilized with $100 \%$ PLA compared with 
Table 1. Effect of SP, PLA, and combinations thereof as P sources on growth index of Lantana camara 'New Gold' throughout an 84-d experimental period.

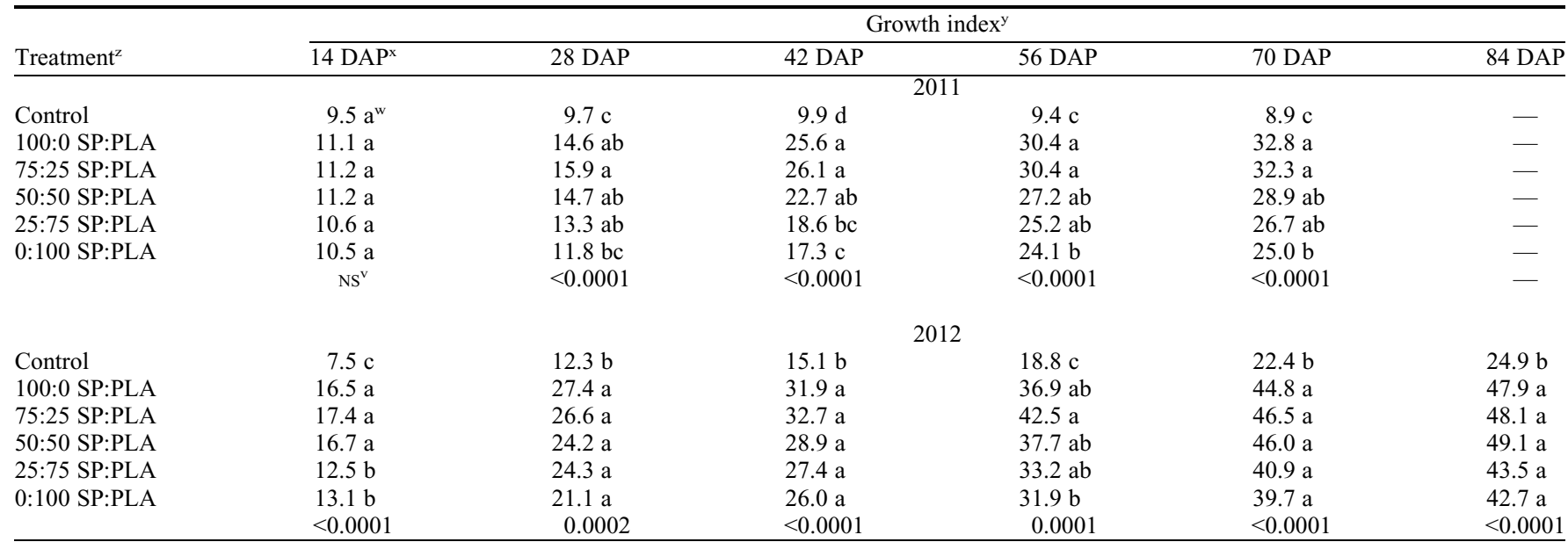

${ }^{\mathrm{z}} \mathrm{Control}=$ no exogenous phosphorus $(\mathrm{P})$ applied; $\mathrm{SP}=$ superphosphate; PLA = poultry litter ash.

${ }^{y}$ Growth index was measured in centimeters as: [(height + widest width + perpendicular width $) / 3$ ]

${ }^{\mathrm{x}} \mathrm{DAP}=$ days after potting.

${ }^{w}$ Values in columns sharing a letter were not significantly different according to Tukey's Honest Significance Difference test $(\alpha=0.05)$.

${ }^{\vee} P$ value derived from analysis of variance; $\mathrm{NS}=$ not significant.

Table 2. Effect of SP, PLA, and combinations thereof as P sources on biomass accumulation of Lantana camara 'New Gold' during an 84-d experimental period.

\begin{tabular}{|c|c|c|c|c|c|c|}
\hline \multirow[b]{2}{*}{ Treatment ${ }^{2}$} & \multicolumn{3}{|c|}{2011} & \multicolumn{3}{|c|}{2012} \\
\hline & Shoot DW $(\mathrm{g})$ & Root DW (g) & Shoot:root & Shoot DW (g) & Root DW (g) & Shoot:root \\
\hline 100:0 SP:PLA & $18.2 \mathrm{a}$ & $5.6 \mathrm{~b}$ & $3.1 \mathrm{a}$ & $25.2 \mathrm{a}$ & $8.3 \mathrm{ab}$ & $2.9 \mathrm{a}$ \\
\hline 25:75 SP:PLA & $11.9 \mathrm{c}$ & $4.7 \mathrm{bc}$ & $2.7 \mathrm{a}$ & $21.9 \mathrm{~b}$ & $7.7 \mathrm{~b}$ & $2.7 \mathrm{a}$ \\
\hline 0:100 SP:PLA & $10.8 \mathrm{c}$ & $4.0 \mathrm{c}$ & $2.7 \mathrm{a}$ & $21.8 \mathrm{~b}$ & $7.9 \mathrm{~b}$ & $2.7 \mathrm{a}$ \\
\hline & $<0.0001^{\mathrm{w}}$ & $<0.0001$ & $<0.0001$ & $<0.0001$ & $<0.0001$ & $<0.0001$ \\
\hline
\end{tabular}

${ }^{\mathrm{z}}$ Control $=$ no exogenous phosphorus $(\mathrm{P})$ applied; $\mathrm{SP}=$ superphosphate; PLA = poultry litter ash.

${ }^{\mathrm{y}}$ Shoot and root biomasses (DW) were measured at $84 \mathrm{DAP}$.

${ }^{\mathrm{x}}$ Values in columns sharing a letter were not significantly different according to Tukey's Honest Significance Difference test $(\alpha=0.05)$.

${ }^{\mathrm{w}} P$ value derived from analysis of variance; $\mathrm{Ns}=$ not significant.

$100 \%$ SP. However, shoot:root biomass ratios did not differ between any P treatments. In 2012, when shoot growth responses between $100 \%$ SP- or PLA-fertilized plants were lessened, no differences in root growth were observed. As in 2011, no differences between shoot:root biomass ratios existed between P treatments in 2012. Shoot:root biomass was increased by $\mathrm{P}$ application, regardless of source or combination of sources in both years, illustrating a larger disparity in shoot mass than root mass based on $\mathrm{P}$ application.

Tissue nutrient accumulation. All P sources increased lantana foliar $P$ concentrations compared with controls in 2011 (Table 3). As the percentage of PLA increased, foliar P concentrations decreased slightly from $0.37 \%$ to $0.33 \%$ in $100 \%$ SP- and $100 \%$ PLA-fertilized lantana, respectively. Lantana fertilized with $100 \%$ PLA had foliar Mn concentrations reduced by $49 \%$, from 226 to $116 \mathrm{mg} \cdot \mathrm{kg}^{-1}$ and foliar $\mathrm{K}$ concentrations increased $52 \%$ from $1.81 \%$ to $2.76 \%$ compared with $100 \%$ SP-fertilized lantana.

In 2012, when differences in plant growth between $\mathrm{P}$ treatments were muted, shoot $\mathrm{P}$ concentrations were lower for plants fertilized with $100 \%$ SP than they were for lantana fertilized with PLA (Table 3). Shoot P concentrations increased from $0.17 \%$ for $100 \%$ SP-fertilized lantana to $0.2 \%$ for $100 \%$ PLA-fertilized lantana, whereas control plants were $0.05 \% \mathrm{P}$.

Dissolved reactive $P$. Lantana fertilized with $100 \%$ PLA had lower concentrations of leachate DRP for the first 6 weeks of experimental periods in 2011 and 2012, compared with plants fertilized with $100 \%$ SP. Lantana fertilized with $100 \%$ PLA resulted in an average decrease in DRP concentrations of $91 \%$ and $94 \%$ in 2011 and 2012, respectively, throughout the 84-d experimental periods compared with lantana fertilized with $100 \%$ SP (Table 4). Increasing the percentage of PLA as a component of $\mathrm{P}$ fertilizer treatments in $25 \%$ gradations reduced average leachate-DRP concentrations by $40 \%, 67 \%$, and $88 \%$ in 2011 and $42 \%, 68 \%$, and $87 \%$ in 2012 compared with $100 \%$ SP-fertilized lantana. All lantana fertilized with treatments containing SP exhibited higher initial leachate-DRP concentrations at 0 DAP with $499,288,96$, and $42 \mathrm{mg} \cdot \mathrm{L}^{-1}$ in 2011 and $513,296,150$, and $51 \mathrm{mg} \cdot \mathrm{L}^{-1}$ in 2012 with subsequent DRP leachate losses declining over time. Lantana fertilized with $100 \%$ PLA resulted in leachate-DRP concentrations reaching maxima of $14 \mathrm{mg} \cdot \mathrm{L}^{-1}$ in each year of the experiment.

Total P effluent mass loss collected in an effluent collection system. Effluent-TP mass loss was higher for all P treatments at 14, 28, 42, 56, and 70 DAP compared with the control (Table 5). Similar to leachate-DRP concentrations, cumulative effluent-TP mass loss was reduced $69 \%$, from 348.5 to 106.5 $\mathrm{mg} /$ container, when PLA was applied as a single $\mathrm{P}$ source. For the experiment, $77 \%$ of applied P, from $100 \% \mathrm{SP}$, was collected in effluent compared with only $24 \%$ from PLA. At 14 DAP, $76 \%$ of cumulative TP was collected from SP, compared with $25 \%$ from PLA (Table 4). Whereas 76\%, 92\%, 98\%, and $99 \%$ of cumulative TP was collected from the $100 \%$ SP treatment by $14,28,42$, and 56 DAP, respectively, TP was released from the $100 \%$ PLA treatment more slowly as $25 \%, 48 \%, 72 \%, 86 \%$, and $95 \%$ of cumulative effluent-TP was collected from PLA on the same respective collection dates.

Application of $\mathrm{P}$, regardless of source, increased shoot dry weight of lantana grown in a closed system compared with control plants (Table 6), but there were no differences between P treatments. Similarly, root dry weights did not differ between $\mathrm{P}$ 
Table 3. Effect of SP, PLA, and combinations thereof, as P sources on tissue nutrient concentrations of Lantana camara 'New Gold' grown in drain-to-waste and effluent collection systems in 2011 and 2012, respectively.

\begin{tabular}{|c|c|c|c|c|c|c|c|c|c|c|}
\hline \multirow[b]{2}{*}{ Treatment $^{\mathrm{z}}$} & \multicolumn{5}{|c|}{ Foliar $^{\mathrm{y}}(2011)$} & \multicolumn{5}{|c|}{ Entire shoots ${ }^{\mathrm{x}}(2012)$} \\
\hline & $\mathrm{Ca}(\%)$ & $\operatorname{Mg}(\%)$ & $\operatorname{Mn}\left(\mathrm{mg} \cdot \mathrm{kg}^{-1}\right)$ & $\mathrm{P}(\%)$ & K (\%) & $\mathrm{Ca}(\%)$ & $\operatorname{Mg}(\%)$ & $\operatorname{Mn}\left(\mathrm{mg} \cdot \mathrm{kg}^{-1}\right)$ & $\mathrm{P}(\%)$ & K (\%) \\
\hline Control & $0.83 \mathrm{a}^{\mathrm{w}}$ & $0.49 \mathrm{a}$ & $226.5 \mathrm{a}$ & $0.03 \mathrm{~d}$ & $3.24 \mathrm{a}$ & $0.67 \mathrm{c}$ & $0.28 \mathrm{c}$ & $355.4 \mathrm{~b}$ & $0.05 \mathrm{c}$ & $1.32 \mathrm{a}$ \\
\hline 100:0 SP:PLA & $1.04 \mathrm{a}$ & $0.42 \mathrm{abc}$ & $225.5 \mathrm{a}$ & $0.37 \mathrm{ab}$ & $1.81 \mathrm{~d}$ & $0.70 \mathrm{bc}$ & $0.62 \mathrm{a}$ & $463.1 \mathrm{a}$ & $0.17 \mathrm{~b}$ & $0.48 \mathrm{~d}$ \\
\hline 75:25 SP:PLA & $0.97 \mathrm{a}$ & $0.45 \mathrm{ab}$ & $187.9 \mathrm{~b}$ & $0.39 \mathrm{a}$ & $1.98 \mathrm{~cd}$ & $0.73 \mathrm{bc}$ & $0.49 \mathrm{ab}$ & $435.8 \mathrm{ab}$ & $0.19 \mathrm{a}$ & $0.59 \mathrm{~cd}$ \\
\hline 50:50 SP:PLA & $0.94 \mathrm{a}$ & $0.42 \mathrm{abc}$ & $158.2 \mathrm{bc}$ & $0.36 \mathrm{abc}$ & $2.29 \mathrm{bcd}$ & $0.83 \mathrm{ab}$ & $0.50 \mathrm{~b}$ & $370.9 \mathrm{~b}$ & $0.20 \mathrm{a}$ & $0.57 \mathrm{~cd}$ \\
\hline 25:75 SP:PLA & $0.85 \mathrm{a}$ & $0.40 \mathrm{bc}$ & $147.1 \mathrm{~cd}$ & $0.34 \mathrm{bc}$ & $2.57 \mathrm{abc}$ & $0.92 \mathrm{a}$ & $0.49 \mathrm{~b}$ & $242.2 \mathrm{c}$ & $0.21 \mathrm{a}$ & $0.76 \mathrm{c}$ \\
\hline 0:100 SP:PLA & $0.86 \mathrm{a}$ & $0.35 \mathrm{c}$ & $115.9 \mathrm{~d}$ & $0.33 \mathrm{c}$ & $2.76 \mathrm{ab}$ & $0.89 \mathrm{a}$ & $0.44 \mathrm{~b}$ & $168.7 \mathrm{c}$ & $0.20 \mathrm{a}$ & $0.84 \mathrm{~b}$ \\
\hline & $\mathrm{NS}^{\mathrm{v}}$ & 0.0066 & $<0.0001$ & $<0.0001$ & 0.0003 & $<0.0001$ & $<0.0001$ & $<0.0001$ & $<0.0001$ & $<0.0001$ \\
\hline
\end{tabular}

${ }^{\mathrm{z}}$ Control = no exogenous phosphorus $(\mathrm{P})$ applied; SP $=$ superphosphate; PLA = poultry litter ash.

${ }^{\mathrm{y}}$ Most recently matured and fully opened leaves.

${ }^{\mathrm{x}}$ Entire top portion of plant including stems, leaves, and flowers.

${ }^{\mathrm{w}}$ Values in columns sharing a letter were not significantly different according to Tukey's Honest Significance Difference test $(\alpha=0.05)$.

${ }^{\mathrm{v}} P$ value derived from analysis of variance; Ns $=$ not significant.

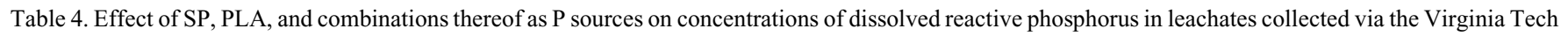
pour through method in 84-d experiments in 2011 and 2012.

\begin{tabular}{|c|c|c|c|c|c|c|c|c|}
\hline \multirow[b]{2}{*}{ Treatment $^{\mathrm{z}}$} & \multicolumn{8}{|c|}{ Dissolved reactive $\mathrm{P}^{\mathrm{y}}\left(\mathrm{mg} \cdot \mathrm{L}^{-1} \mathrm{P}\right)$} \\
\hline & $0 \mathrm{DAP}^{\mathrm{x}}$ & 14 DAP & 28 DAP & 42 DAP & 56 DAP & 70 DAP & 84 DAP & Avg \\
\hline & \multicolumn{8}{|c|}{2011} \\
\hline Control & $0.36 \mathrm{e}^{\mathrm{w}}$ & $0.23 \mathrm{~d}$ & $0.28 \mathrm{~d}$ & $0.36 \mathrm{c}$ & $0.30 \mathrm{~b}$ & $0.22 \mathrm{~b}$ & $0.19 \mathrm{c}$ & $0.28 \mathrm{~d}$ \\
\hline 100:0 SP:PLA & $499.9 \mathrm{a}$ & $178.9 \mathrm{a}$ & $134.9 \mathrm{a}$ & $34.2 \mathrm{a}$ & $6.2 \mathrm{a}$ & $3.8 \mathrm{a}$ & $1.6 \mathrm{~b}$ & $122.8 \mathrm{a}$ \\
\hline 75:25 SP:PLA & $287.7 \mathrm{~b}$ & $108.6 \mathrm{~b}$ & $83.7 b$ & $23.7 \mathrm{ab}$ & $6.9 \mathrm{a}$ & $4.0 \mathrm{a}$ & $2.1 \mathrm{ab}$ & $73.8 \mathrm{~b}$ \\
\hline 50:50 SP:PLA & $96.1 \mathrm{c}$ & $61.5 \mathrm{bc}$ & $56.9 \mathrm{~b}$ & $15.8 \mathrm{ab}$ & $5.5 \mathrm{a}$ & $4.4 \mathrm{a}$ & $4.7 \mathrm{a}$ & $40.6 \mathrm{bc}$ \\
\hline 25:75 SP:PLA & $41.8 \mathrm{~cd}$ & $26.5 \mathrm{c}$ & $16.9 \mathrm{c}$ & $8.6 \mathrm{~b}$ & $5.0 \mathrm{a}$ & $4.8 \mathrm{a}$ & $2.6 \mathrm{ab}$ & $15.2 \mathrm{c}$ \\
\hline \multirow[t]{3}{*}{ 0:100 SP:PLA } & $3.8 \mathrm{~d}$ & $14.1 \mathrm{c}$ & $12.1 \mathrm{c}$ & $8.9 \mathrm{~b}$ & $6.8 \mathrm{a}$ & $4.5 \mathrm{a}$ & $2.9 \mathrm{ab}$ & $11.2 \mathrm{c}$ \\
\hline & $<0.0001^{\mathrm{v}}$ & $<0.0001$ & $<0.0001$ & $<0.0001$ & $<0.0001$ & $<0.0001$ & $<0.0001$ & $<0.0001$ \\
\hline & \multicolumn{8}{|c|}{2012} \\
\hline Control & $0.41 \mathrm{f}$ & $0.20 \mathrm{e}$ & $0.28 \mathrm{e}$ & $0.28 \mathrm{e}$ & $0.25 \mathrm{~b}$ & $0.23 \mathrm{~b}$ & $0.20 \mathrm{~b}$ & $0.26 \mathrm{~d}$ \\
\hline 100:0 SP:PLA & $513.4 \mathrm{a}$ & $159.4 \mathrm{a}$ & $113.4 \mathrm{a}$ & $20.3 \mathrm{a}$ & $4.9 \mathrm{a}$ & $3.2 \mathrm{a}$ & $2.1 \mathrm{a}$ & $116.7 \mathrm{a}$ \\
\hline 75:25 SP:PLA & $295.6 \mathrm{~b}$ & $107.1 \mathrm{~b}$ & $49.9 \mathrm{~b}$ & $12.4 \mathrm{~b}$ & $4.4 \mathrm{a}$ & $2.9 \mathrm{a}$ & $1.5 \mathrm{a}$ & $67.7 \mathrm{~b}$ \\
\hline 50:50 SP:PLA & $150.4 \mathrm{c}$ & $57.1 \mathrm{c}$ & $33.5 \mathrm{bc}$ & $10.7 \mathrm{bc}$ & $4.7 \mathrm{a}$ & $3.5 \mathrm{a}$ & $1.6 \mathrm{a}$ & $37.3 \mathrm{bc}$ \\
\hline 25:75 SP:PLA & $50.8 \mathrm{~d}$ & $25.1 \mathrm{~cd}$ & $16.9 \mathrm{~cd}$ & $7.1 \mathrm{~d}$ & $3.9 \mathrm{a}$ & $3.6 \mathrm{a}$ & $1.6 \mathrm{a}$ & $15.6 \mathrm{c}$ \\
\hline \multirow[t]{2}{*}{ 0:100 SP:PLA } & $3.5 \mathrm{e}$ & $14.5 \mathrm{~d}$ & $12.9 \mathrm{~d}$ & $8.0 \mathrm{~cd}$ & $6.1 \mathrm{a}$ & $4.2 \mathrm{a}$ & $2.3 \mathrm{a}$ & $7.4 \mathrm{c}$ \\
\hline & $<0.0001$ & $<0.0001$ & $<0.0001$ & $<0.0001$ & $<0.0001$ & $<0.0001$ & $<0.0001$ & $<0.0001$ \\
\hline
\end{tabular}

${ }^{\mathrm{z}}$ Control = no exogenous phosphorus $(\mathrm{P})$ applied; $\mathrm{SP}=$ superphosphate; PLA = poultry litter ash.

${ }^{\mathrm{y}}$ Concentration of soluble orthophosphate collected in leachate.

${ }^{\mathrm{x}} \mathrm{DAP}=$ days after potting.

${ }^{\mathrm{w}}$ Values in columns sharing a letter were not significantly different according to Tukey's Honest Significance Difference test $(\alpha=0.05)$

${ }^{\mathrm{v}} P$ value derived from analysis of variance.

Table 5. Effects of SP, PLA, and combinations thereof as P sources on total P in effluent from Lantana camara 'New Gold' grown in an effluent collection system over an 84-d experimental period in 2012.

\begin{tabular}{|c|c|c|c|c|c|c|c|}
\hline \multirow[b]{2}{*}{ Treatment $^{\mathrm{z}}$} & \multicolumn{7}{|c|}{ Effluent-total $\mathrm{P}(\mathrm{mg})^{\mathrm{y}}$} \\
\hline & $14 \mathrm{DAP}^{\mathrm{x}}$ & 28 DAP & 42 DAP & 56 DAP & 70 DAP & 84 DAP & Total \\
\hline Control & $0.7 \mathrm{f}^{\mathrm{w}}$ & $0.3 \mathrm{c}$ & $0.6 \mathrm{c}$ & $0.8 \mathrm{~d}$ & $0.5 \mathrm{~d}$ & $0.8 \mathrm{e}$ & $3.8 \mathrm{e}$ \\
\hline 100:0 SP:PLA & $265.3 \mathrm{a}$ & $55.2 \mathrm{a}$ & $19.6 \mathrm{ab}$ & $3.8 \mathrm{bc}$ & $3.4 \mathrm{bc}$ & $1.1 \mathrm{de}$ & $348.5 \mathrm{a}$ \\
\hline 75:25 SP:PLA & $186.5 \mathrm{~b}$ & $54.8 \mathrm{a}$ & $11.5 \mathrm{~b}$ & $2.7 \mathrm{c}$ & $2.1 \mathrm{c}$ & $1.7 \mathrm{bc}$ & $259.5 \mathrm{~b}$ \\
\hline 50:50 SP:PLA & $117.4 \mathrm{c}$ & $33.5 \mathrm{~b}$ & $12.1 \mathrm{~b}$ & $4.9 \mathrm{~b}$ & $3.4 \mathrm{bc}$ & $1.4 \mathrm{~cd}$ & $172.9 \mathrm{c}$ \\
\hline 25:75 SP:PLA & $68.7 \mathrm{~d}$ & $25.1 \mathrm{~b}$ & $11.5 \mathrm{~b}$ & $4.1 \mathrm{bc}$ & $4.5 \mathrm{~b}$ & $2.1 \mathrm{~b}$ & $116.2 \mathrm{~d}$ \\
\hline 0:100 SP:PLA & $26.6 \mathrm{e}$ & $25.0 \mathrm{~b}$ & $25.0 \mathrm{a}$ & $15.3 \mathrm{a}$ & $8.8 \mathrm{a}$ & $5.6 \mathrm{a}$ & $106.5 \mathrm{~d}$ \\
\hline & $<0.0001^{\mathrm{v}}$ & $<0.0001$ & $<0.0001$ & $<0.0001$ & $<0.0001$ & $<0.0001$ & $<0.000$ \\
\hline
\end{tabular}

${ }^{\mathrm{z}}$ Treatments were the following: control = no exogenous phosphorus $(\mathrm{P})$ applied; SP = superphosphate; PLA = poultry litter ash.

${ }^{\mathrm{y}} \mathrm{A}$ total of $450 \mathrm{mg} \mathrm{P}$ was added to system at experiment initiation.

${ }^{\mathrm{x}}$ Days after potting.

${ }^{\text {w}}$ Values in columns sharing a letter were not significantly different according to Tukey's Honest Significance Difference test $(\alpha=0.05)$.

${ }^{\mathrm{v}} P$ value derived from analysis of variance; $\mathrm{NS}=$ not significant.

treatments, and shoot:root biomass increased because of $\mathrm{P}$ application, regardless of source.

Effects of $P$ source on posttransplant growth in field. During production, P source only affected landscape performance of lantana during the initial weeks after planting. Lantana fertilized with $\mathrm{P}$ during production, regardless of treatment, had a greater growth index than control plants at 0,7 , and 14 DAP.
From 21 DAP onwards, plants in the control group were as large as plants that were fertilized with $\mathrm{P}$ during container production, with the exception of the $100 \%$ SP treatment group, which remained larger than control plants for the duration of the field experiment (Table 7). At the end of the 49-d experimental period, lantana shoot biomass did not differ among production treatments, including the control group.

\section{Discussion}

Poultry litter ash has been reported as a potentially-suitable $\mathrm{P}$ source for greenhouse crop production with liming potential to improve substrate $\mathrm{pH}$ (Wells et al., 2013). However, the most positive attribute of PLA as a $\mathrm{P}$ fertilizer for greenhouse crop production may be its potential to reduce P-leaching losses. In the current experiments, lantana 
fertilized with $100 \%$ PLA exhibited reductions in DRP and TP losses by averages of $92 \%$ and $69 \%$, respectively, compared with lantana fertilized with $100 \%$ SP. Reductions in initial DRP losses were disproportionate to the percentage of PLA applied. For example, replacement of the SP fraction of the P fertilizer with $25 \%, 50 \%$, and $75 \%$ PLA resulted in initial DRP reductions of $45 \%, 70 \%$, and $86 \%$, respectively. Use of readily available nutrients early in crop production is questionable (Altland and Buamscha, 2008) from an environmental as well as a production standpoint. To concur with the work of Altland and Buamscha (2008), limited plant rooting associated with developing plants restricts exploitation of the substrate and thus necessity of soluble nutrients early in the production cycle.

Even though all experimental units received the same volume of water during daily irrigation, leachate-DRP concentrations decreased each subsequent week for all SPcontaining fertilizer treatments, whereas lantana fertilized with $100 \%$ PLA remained relatively stable ranging from 3 to $14 \mathrm{mg} \cdot \mathrm{L}^{-1}$ for the first 10 WAP. These differences in leachate-DRP concentrations suggest that PLA-P solubility, a factor known to affect

Table 6. Effects of SP, PLA, and combinations thereof as $\mathrm{P}$ sources on biomass accumulation of Lantana camara 'New Gold' grown in a closed system over an 84-d experimental period in 2012.

\begin{tabular}{lccc}
\hline & \multicolumn{3}{c}{${\text { Dry } \mathrm{wt}^{\mathrm{y}}}$} \\
\cline { 2 - 4 } Treatment $^{\mathrm{z}}$ & Shoot $(\mathrm{g})$ & Root $(\mathrm{g})$ & Shoot:root \\
\hline Control & $9.68 \mathrm{~b}^{\mathrm{x}}$ & $6.77 \mathrm{~b}$ & $1.44 \mathrm{~b}$ \\
100:0 SP:PLA & $32.56 \mathrm{a}$ & $8.88 \mathrm{ab}$ & $3.75 \mathrm{a}$ \\
75:25 SP:PLA & $32.59 \mathrm{a}$ & $10.19 \mathrm{a}$ & $3.22 \mathrm{a}$ \\
50:50 SP:PLA & $38.04 \mathrm{a}$ & $10.21 \mathrm{a}$ & $3.75 \mathrm{a}$ \\
25:75 SP:PLA & $27.74 \mathrm{a}$ & $8.15 \mathrm{ab}$ & $3.41 \mathrm{a}$ \\
0:100 SP:PLA & $32.14 \mathrm{a}$ & $8.75 \mathrm{ab}$ & $3.70 \mathrm{a}$ \\
& $<0.0001^{\mathrm{w}}$ & 0.0282 & 0.0027 \\
\hline
\end{tabular}

${ }^{\mathrm{z}}$ Treatments were the following: control $=$ no exogenous phosphorus (P) applied; $\mathrm{SP}=$ superphosphate; PLA = poultry litter ash.

${ }^{\mathrm{y}}$ Shoot and root dried biomasses were measured in grams while shoot:root ratio is unitless.

${ }^{\mathrm{x}}$ Values in columns sharing a letter were not significantly different according to Tukey's Honest Significance Difference test $(\alpha=0.05)$.

${ }^{\mathrm{w}} P$ value derived from analysis of variance; $\mathrm{NS}=$ not significant.
P-leaching losses, is less affected by water usage compared with more highly soluble $\mathrm{P}$ sources during crop production. According to Raviv and Lieth (2008), solution P concentrations for most greenhouse crops should fall between 5 and $60 \mathrm{mg} \cdot \mathrm{L}^{-1}$, whereas a narrower range of 5 to $10 \mathrm{mg} \cdot \mathrm{L}^{-1}$ is recommended for container-grown crops when employing CRFs (Yeager et al., 2007). However, overapplication of $\mathrm{P}$ is often the result of target $\mathrm{N}$ fertilization rates of complete, water-soluble fertilizers commonly applied to greenhouse crops (Smith et al., 2004).

Monocalcium phosphate, with a water solubility of $20,000 \mathrm{mg} \cdot \mathrm{L}^{-1}$ water (Van Wazer, 1958), is the primary P-containing compound within SP (Prochnow et al., 2003). Although TP content is somewhat similar for SP and PLA, on average $93 \%$ of SP-P is highly watersoluble (Gowariker, 2009), whereas a lower fraction of PLA-P is water-soluble (Codling, 2006). This is likely due to formation, during combustion, of highly water-insoluble di- and tricalcium phosphates having water solubilities of 200 and $20 \mathrm{mg} \cdot \mathrm{L}^{-1}$ water, respectively (Van Wazer, 1958).

Given the lack of P-sorption capacities of common substrate components (Bilderback, 2001; Khandan-Mirkohi and Schenk, 2008), P is lost from soilless substrates relatively quickly if applied in highly water-soluble forms. Yeager and Barrett (1984) reported up to 37\% of $\mathrm{P}$, applied as SP, leached within $1 \mathrm{~d}$ after application with up to $76 \% \mathrm{P}$ losses within $21 \mathrm{~d}$ after application. In a subsequent experiment, Yeager and Barrett (1986) reported $80 \%$ of applied $\mathrm{P}$ leached within $21 \mathrm{~d}$ from a substrate composed of pine bark, peatmoss, and sand. Therefore, reductions in $\mathrm{P}$ losses through application of PLA during container production are mostly likely a direct result of reduced PLA-P water-solubility in comparison with the more highly water-soluble SP-P.

Given the positive environmental attributes of PLA as a P fertilizer source in container crop production, it is important to evaluate the effect of PLA on plant growth and quality. In these experiments, growth differences in lantana were inconsistent between years. In 2011, lantana fertilized with $100 \%$ PLA reduced growth indices $33 \%$, $21 \%$, and $24 \%$ at 42,56 , and 70 DAP, respectively, compared with those fertilized with $100 \%$ SP. These reductions in growth of PLA-fertilized lantana were accompanied with reduced shoot and root biomasses of $41 \%$ and $28 \%$ compared with $100 \%$ SPfertilized lantana. As the portion of SP increased, lantana growth and shoot biomass increased. In 2012, shoot dry weight difference between $100 \%$-SP fertilized plants and $100 \%$ PLA-fertilized plants declined to $14 \%$, whereas no differences in root biomass were measured. This, along with the fact that shoot:root biomass ratios, which commonly indicate P-deficiency in crops (Mengel and Kirkby, 1987), did not differ between $P$ treatments in either year suggests decreased root growth was the primary factor driving differences in shoot biomass.

More likely, the differences in lantana response to P-fertilization treatments in 2011 and 2012 may be the result of environmental conditions. During 2011, plants were grown at an average daily temperature of $23.7^{\circ} \mathrm{C}$ with shorter daylengths compared with $28.4{ }^{\circ} \mathrm{C}$ and longer day lengths in 2012. Temperature has been shown to affect vigor and rooting of container grown plants (Mathers et al., 2007). Delayed lantana rooting would have limited root interaction with PLA. Interaction of lantana roots with less soluble $P$ sources, such as PLA, is an important mechanism for releasing $P$ in plant-available forms (Hinsinger, 2001). In a multiyear experiment comparing $P$ fertilizer source and placement on P availability to eucalyptus in an acidic Brazilian oxisol, Dias et al. (2000) reported eucalyptus root systems increased $\mathrm{P}$ dissolution rates of low soluble rock phosphates for increased plant uptake. Rhizospheric chemical conditions differ significantly from the surrounding bulk soil or substrate environment because of processes involving ion release, gaseous flux, and exudation of organic ligands. Release of these chemicals around the root alters $\mathrm{pH}$ to affect $\mathrm{P}$ solubility, thus availability (Hinsinger, 2001). Therefore, environmental factors will greatly affect PLA-P plant availability as a function of root growth and interaction.

The lack of growth and quality differences observed in the postproduction field trial, between lantana fertilized with highand low-soluble P sources, further highlights the benefits of using low soluble P sources for container plant production. The endpoints for

Table 7. Effects of SP, PLA, and combinations thereof as P sources during greenhouse production on postproduction growth index and shoot biomass dry weight under simulated landscape conditions of Lantana camara 'New Gold' in 2012.

\begin{tabular}{|c|c|c|c|c|c|c|c|c|c|}
\hline \multirow[b]{2}{*}{ Treatment $^{\mathrm{z}}$} & \multicolumn{8}{|c|}{ Growth index ${ }^{y}$} & \multirow{2}{*}{$\frac{\text { Shoot DW }(\mathrm{g})}{49 \mathrm{DAP}}$} \\
\hline & $0 \mathrm{DAP}^{\mathrm{x}}$ & 7 DAP & 14 DAP & $21 \mathrm{DAP}$ & 28 DAP & 35 DAP & 42 DAP & 49 DAP & \\
\hline Control & $38.9 b^{w}$ & $39.1 \mathrm{~b}$ & $42.6 \mathrm{~b}$ & $48.9 \mathrm{~b}$ & $82.3 \mathrm{~b}$ & $88.9 \mathrm{~b}$ & $90.6 \mathrm{~b}$ & $93.8 \mathrm{~b}$ & $421.8 \mathrm{a}$ \\
\hline 100:0 SP:PLA & $67.9 \mathrm{a}$ & $59.9 \mathrm{a}$ & $60.5 \mathrm{a}$ & $61.4 \mathrm{ab}$ & $99.7 \mathrm{a}$ & $101.3 \mathrm{a}$ & $104.2 \mathrm{a}$ & $109.0 \mathrm{a}$ & $571.0 \mathrm{a}$ \\
\hline 75:25 SP:PLA & $69.9 \mathrm{a}$ & $61.1 \mathrm{a}$ & $61.1 \mathrm{a}$ & $64.1 \mathrm{a}$ & $90.4 \mathrm{ab}$ & $94.8 \mathrm{ab}$ & $97.1 \mathrm{ab}$ & $101.3 \mathrm{ab}$ & $569.5 \mathrm{a}$ \\
\hline 50:50 SP:PLA & $65.1 \mathrm{a}$ & $59.2 \mathrm{a}$ & $59.2 \mathrm{a}$ & $63.4 \mathrm{a}$ & $95.4 \mathrm{a}$ & $97.6 \mathrm{ab}$ & $100.1 \mathrm{ab}$ & $103.7 \mathrm{ab}$ & $571.3 \mathrm{a}$ \\
\hline 25:75 SP:PLA & $68.2 \mathrm{a}$ & $58.9 \mathrm{a}$ & $59.6 \mathrm{a}$ & $63.2 \mathrm{a}$ & $93.8 \mathrm{ab}$ & $98.0 \mathrm{ab}$ & $100.7 \mathrm{ab}$ & $104.7 \mathrm{ab}$ & $524.7 \mathrm{a}$ \\
\hline 0:100 SP:PLA & $61.5 \mathrm{a}$ & $61.1 \mathrm{a}$ & $56.7 \mathrm{a}$ & $60.7 \mathrm{ab}$ & $93.9 \mathrm{ab}$ & $97.6 \mathrm{ab}$ & $100.2 \mathrm{ab}$ & $103.7 \mathrm{ab}$ & $521.8 \mathrm{a}$ \\
\hline & $<0.0001^{\mathrm{v}}$ & 0.0003 & 0.0032 & 0.0215 & 0.0052 & 0.0434 & 0.0413 & 0.049 & NS \\
\hline
\end{tabular}

${ }^{\mathrm{z}}$ Treatments were the following: control = no exogenous phosphorus $(\mathrm{P})$ applied; $\mathrm{SP}=$ superphosphate; PLA $=$ poultry litter ash.

${ }^{y}$ Growth index was measured in centimeters as: [(height + widest width + perpendicular width)/3].

${ }^{\mathrm{x}} \mathrm{DAP}=$ days after potting.

${ }^{w}$ Values in columns sharing a letter were not significantly different according to Tukey's Honest Significance Difference test $(\alpha=0.05)$.

${ }^{\mathrm{v}} P$ value derived from analysis of variance; ns = not significant. 
greenhouse grown ornamental crops are either larger containers or constructed landscapes. In either case, postproduction fertilizers, including $\mathrm{P}$, are used to further the crop's effective lifespan and can offset minor differences in growth or flowering observed during production.

\section{Conclusions}

Mitigating P losses from container-grown plant production sites poses a challenge to responsible growers in the nursery and greenhouse industries. Recycled P, in the form of low water-soluble biomass ash, such as PLA, has the potential to limit environmental impact of $P$. Use of PLA in lantana production reduced leachate-DRP concentrations and TP mass losses, by averages of $92 \%$ and $69 \%$, respectively, compared with plants fertilized with $100 \%$ SP, a highly water-soluble $\mathrm{P}$ source. Application of PLA as a P-fertilizer amendment did limit lantana growth and extended the production duration under less-than-suitable environmental conditions. Plant zavailability of PLA-P, which is influenced by root rhizosphere reactions, may not be suitable for all crops and substrate combinations. However, from an environmental protection standpoint, the benefit of P-loss reduction during container production achieved through PLA application may warrant the acceptance of slight decreases in plant size observed during crop production especially when considering the offset of those slight decreases in postproduction landscapes.

\section{Literature Cited}

Altland, J.E. and M.G. Buamscha. 2008. Nutrient availability from douglas fir bark in response to substrate $\mathrm{pH}$. HortScience 43:478-483.

AOAC INTERNATIONAL. 2005a. Official methods of analysis of AOAC INTERNATIONAL. 18th ed. AOAC INTERNATIONAL, Gaithersburg, MD. AOAC 970.01.

AOAC INTERNATIONAL. 2005b. Official methods of analysis of AOAC INTERNATIONAL. 18th ed. AOAC INTERNATIONAL, Gaithersburg, MD. AOAC 978.01.

AOAC INTERNATIONAL. 2005c. Official methods of analysis of AOAC INTERNATIONAL. 18th ed. AOAC INTERNATIONAL, Gaithersburg, MD. AOAC 993.31.

Bachmann, S. and B. Eichler-Lobermann. 2010. Soil phosphorus pools as affected by application of poultry litter ash in combination with catch crop cultivation. Commun. Soil Sci. Plant Anal. 41:1098-1111.

Bernhart, M., O.O. Fasina, C.W. Wood, and J. Fulton. 2010. Compaction of poultry litter. Bioresour. Technol. 101:234-238.

Bilderback, T.E. 2001. Environmentally compatible container plant production practices. Proc. Int. Symp. on Growing Media \& Hydroponics. Acta Hort. 548:311-318. ISHS.

Brodie, H.L., L.E. Carr, and P. Condon. 2000. A comparison of static pile and turned windrow methods for poultry litter compost production. Compost Sci. Util. 8:178-189.

Codling, E.E. 2006. Laboratory characterization of extractable phosphorus in poultry litter and poultry litter ash. Soil Sci. 171:858-864.

Codling, E.E., R.L. Chaney, and J. Sherwell. 2002. Poultry litter ash as a potential phosphorus source for agricultural crops. J. Environ. Qual. 31:954-961.

Dawson, C.J. and J. Hilton. 2011. Fertiliser availability in a resource-limited world: Production and recycling of nitrogen and phosphorus. Food Policy 36:S14-S22.

Dias, L.E., J. Fernandez, N. de Barros, R. de Novais, E. de Moraes, and W. Daniels. 2000. Availability of phosphorus in a brazilian oxisol cultivated with eucalyptus after nine years as influenced by phosphorus fertilizer source, rate, and placement. Commun. Soil Sci. Plant Anal. 31:837-847.

Faridullah, M.I., S. Yamamoto, A.E. Eneji, T. Uchiyama, and T. Honna. 2009. Recycling of chicken and duck litter ash as a nutrient source for Japanese mustard spinach. J. Plant Nutr. 32:1082-1091.

Gowariker, V. (ed.). 2009. The Fertilizer Encyclopedia. Wiley, Hoboken, NJ.

Habetz, D. and R. Echols. 2006. Development of successful poultry litter-to-energy furnace. ASABE Paper No. 064185. St. Joseph, Mich. ASABE.

Hinsinger, P. 2001. Bioavailability of soil inorganic $\mathrm{P}$ in the rhizosphere as affected by rootinduced chemical changes: A review. Plant Soil 237:173-195.

Khandan-Mirkohi, A. and M. Schenk. 2008. Phosphorus dynamics in peat-based substrates. J. Plant Nutr. Soil Sci. 171:804-809.

Lea-Cox, J.D. and A.G. Ristvey. 2003. Why are nutrient uptake efficiencies so low in ornamental plant production? Proc. South Nurs. Assoc. Res. Conf. 48:107-111.

Mangiafico, S.S., J. Gan, L. Wu, J. Lu, J.P. Newman, B. Faber, D.J. Merhaut, and R. Evans. 2008. Detention and recycling basins for managing nutrient and pesticide runoff from nurseries. HortScience 43:393-398.

Mathers, H.M., D.K. Struve, L.T. Case, S.B. Lowe, and C. Scragel. 2007. Abiotic factors influencing root growth of woody nursery plants in containers. HortTechnology 17:151-162.

McMullen, J., O.O. Fasina, C.W. Wood, and Y. Feng. 2005. Storage and handling characteristics of pellets from poultry litter. Appl. Eng. Agr. 21:645-651.

Mengel, K. and E.A. Kirkby. 1987. Principles of plant nutrition. 4th ed. International Potash Institute, Bern, Switzerland.

Mills, H.A. and J.B. Jones, Jr. 1996. Plant Analysis Handbook II: A practical sampling, preparation, analysis, and interpretation guide. MicroMacro Publishing, Inc., Athens, GA.

Murphy, J. and J.P. Riley. 1962. A modified single solution method for determination of phosphate in natural waters. Anal. Chim. Acta 27:31-36.

Pote, D.H. and T.C. Daniel. 2000a. Analyzing for dissolved reactive phosphorus in water samples. In: G.M. Pierzynski (ed.). Methods of phosphorus analysis for soils, sediments, residuals, and waters. Southern Cooperative Series Bulletin No. 396. SERA-IEG.

Pote, D.H. and T.C. Daniel. 2000b. Analyzing for total phosphorus and total dissolved phosphorus in water samples. In: G.M. Pierzynski (ed.). Methods of phosphorus analysis for soils, sediments, residuals, and waters. Southern Cooperative Series Bulletin No. 396. SERA-IEG.

Priyadarsan, S., S. Mukhtar, M.T. Holtzapple, K. Annamalai, and J.M. Sweeten. 2004. Fixedbed gasification of feedlot manure and poultry litter biomass. Trans. ASAE 47:1689-1696.

Prochnow, L.I., S.H. Chien, R.W. Taylor, G. Carmona, J. Henao, and E.F. Dillard. 2003. Characterization and agronomic evaluation of single superphosphates varying in iron phosphate impurities. Agron. J. 95:293-302.

Raviv, M. and H. Lieth. 2008. Soilless culture: Theory and practice. Elsevier, Oxford, UK.

Ristvey, A.G., J.D. Lea-Cox, and D.S. Ross. 2007. Nitrogen and phosphorus uptake efficiency and partitioning of container-grown azalea during spring growth. J. Amer. Soc. Hort. Sci. 132:563571.

Schiemenz, K. and B. Eichler-Lobermann. 2010. Biomass ashes and their phosphorus fertilizing effect on different crops. Nutr. Cycl. Agroecosyst. 87:471-482.

Sharpley, A.N., S.C. Chapra, R. Wedepohl, J.T Sims, T.C. Daniel, and K.R. Reddy. 1994. Managing agricultural phosphorus for protection of surface waters: Issues and options. J. Environ. Qual. 23:437-451.

Shaviv, A. 2001. Advances in controlled-release fertilizers. Adv. Agron. 71:1-49.

Silber, A., M. Bruner, E. Kenig, G. Reshef, H. Zohar, I. Posalski, H. Yehezkel, D. Shmuel, S. Cohen, M. Dinar, E. Matan, I. Dinkin, Y. Cohen, L. Karni, B. Aloni, and S. Assouline. 2005. High fertigation frequency and phosphorus level: Effects on summer- grown bell pepper growth and blossom-end rot incidence. Plant Soil 270:135-146.

Smith, B.R., P.R. Fisher, and W.R. Argo. 2004 Water-soluble fertilizer concentration and $\mathrm{pH}$ of a peat-based substrate affect growth, nutrient uptake, and chlorosis of container-grown seed geraniums. J. Plant Nutr. 27:497-524.

Szogi, A.A., M.B. Vanotti, and P.G. Hunt. 2008. Phosphorus recovery from poultry litter. Trans. ASABE 51:1727-1734.

Tyler, H.H., S.L. Warren, and T.E. Bilderback. 1996. Reduced leaching fractions improve irrigation use efficiency and nutrient efficacy. J. Environ. Hort. 14:199-204.

Van Wazer, J.R. 1958. Phosphorus and its compounds. Interscience Publishers, Inc., New York, NY.

Wells, D.E., E.W. Bush, J.S. Beasley, and C.E. Johnson. 2013. Effects of phosphorus source, phosphorus rate, and liming rate on growth and quality of greenhouse-grown Verbena canadensis Britton 'Homestead Purple' and Lantana camara L. 'New Gold'. J. Environ. Hort. 31:94-100.

Wright, R.D. 1986. The pour-thru nutrient extraction procedure. HortScience 21:227-229.

Woyengo, T.A. and C.M. Nyachoti. 2011. Review: Supplementation of phytase and carbohydrases to diets for poultry. Can. J. Anim. Sci. 91:177-192.

Yeager, T.H. and J.E. Barrett. 1984. Phosphorus leaching from ${ }^{32} \mathrm{P}$-superphosphate-amended soilless container media. HortScience 19:216-217.

Yeager, T.H. and J.E. Barrett. 1985. Influence of incubation time on phosphorus leaching from a container medium. J. Environ. Hort. 3:186-187.

Yeager, T.H. and J.E. Barrett. 1986. Influence of an aluminum amendment on phosphorus leaching from a container medium. HortScience 21:262263.

Yeager, T.H. and R.D. Wright. 1982. Pine bark Phosphorus relationships. Commun. Soil Sci. Plant Anal. 13:57-66.

Yeager, T.H., T. Bilderback, D. Fare, C. Gilliam, J. Lea-Cox, A. Niemiera, J. Ruter, K. Tilt, S. Warren, T. Whitwell, and R. Wright. 2007. Best management practices: Guide for producing nursery crops. 2nd ed. The Southern Nursery Association, Atlanta, GA.

Zhu, H., J.M. Frantz, R.C. Derksen, and C.R Krause. 2007. Investigation of drainage and plant growth from nursery container substrate. App. Eng. Ag. 23:289-297. 